\title{
Disparity in Human Rights Violations: A Political and International Law Perspective
}

\author{
Aidir Amin Daud \\ Faculty of Law, Hasanuddin University \\ Jln. Perintis Kemerdekaan KM. 10, Tamalanrea, Makassar 90245, South Sulawesi, Indonesia \\ Tel./Fax:+62-411-587219E-mail:aidirad@yahoo.com
}

Submitted: Sep 9, 2016; Reviewed: Nov 13, 2016; Accepted: Nov 21, 2016

\begin{abstract}
Right to life is non-derogable rights. A natural right that should not be revoked arbitrarily by anyone, including the state. A mass murder in events 1 October 1965 and Timor-Timor is a double series of states' failure in protecting the rights of Indonesian peoples. Moreover, these two events get different treatment in its handling. The disparity in treatment between two cases is a big question related to the consistency of human rights enforcement in Indonesia. This study is a descriptive-qualitative research. While, to prove the truth, this study will use a comparative study. The findings show that the attitude of the United Nations that treat serious human rights violations in Timor-Timor and the events of 1965 in Indonesia, cannot be answered differently in the perspective of international law. Since it has a weakness where the political interests of ruling is very strong in influencing the decisions of the UN. The disparity in law enforcement in the event of serious human rights violations in 1965 and Timor-Timor due to the dynamics of international politics when it does not allow for the demands of human rights violations to the UNs'International Court due to advantage for a certain state after the event. In order to reduce disparities in human rights violations, reconciliation is the most rational solution at this time compared remains demand the state for the violations. Besides, many human rights violations in certain countries that have successfully resolved through reconciliation approach.
\end{abstract}

Keywords: Human Rights; International Criminal Court; Timor-Timor; United Nations

DOI: 10.20956/halrev.v2i3.697

\section{INTRODUCTION}

Indonesia in history has two "stain" in law enforcement of human rights violations. The first, the massacre of former members of the Communist Party of Indonesia in 1965; Second, the oppression of Timor-Timor people post-referendum in $1998 .{ }^{1}$ Two such cases

In addition to these two cases, in fact there are also some cases of serious human rights violations, such as Tanjung Priok, Semanggi and Trisakti. See: Harifin A. Tumpa. (2010). Peluang dan Tantangan Eksistensi Pengadilan HAM di Indonesia. Jakarta: Kencana, pg.71 are known in the literature either written by academics Indonesia or abroad as two greatest human rights violation cases in the history of this republic.

As two cases are quite similar and involve the victim to thousands of people, the handling of these two cases is very contradictory. When there are indications of human rights violations in Timor-Timor is estimated to have killed more than 1.000 
people, ${ }^{2}$ the UN immediately act reactively to establish the Special Panels of Dili District Court, a special forum set up by the UN to follow-up the indications of human rights violations in Timor-Timor. On the other hand, the opposite actions of the UN in addressing mass killings of the events 1 October 1965. In fact, a number of books which contain serious human rights violations throughout the New Order as well as the beginning of reform rarely categorize cases in 1965 as one of the dark history of human rights violations in Indonesia.

The slow response of state as national law enforcement as well as the awkward of United Nations as a superintendent of human rights enforcement of international human rights causes profound anxiety in a number of activists and human rights activists in Indonesia. Departing from the anxiety, the activists in Indonesia in 2014 to initiate the implementation of the International People's Tribunal (IPT) 1965 held in Den Haag, Netherlands. This forum is organized as a means to search for the truth if there have been serious human rights violations in the events of 1965. In its process, the judges of IPT 1965 unanimously and agreed to declare that the Government of Indonesia declared guilty of 10 serious human rights violation, namely the mass killing, imprisonment, enslavement, torture, forced disappearances, sexual violence, exile, false propaganda, engagement with other countries, and genocide against particular groups.

In contrast, as a peoples' court, IPT is not legally binding as a formal courts in gen-

\footnotetext{
2 Geoffrey Robinson, "People's war: Militias in East Timor and Indonesia", Journal South East Asia Research, 9(3): 271-318
}

eral. Ultimately awaited by victims' families is state wisdom to dare to admit that there have been serious human rights violations in the events of 1965 . The reconciliation for victims of human rights violations is the best solution that can be offered at this time. The story of state reconciliation with victims of human rights violations in an effort disclosure of past serious human rights violations is not a new thing in the modern world. The case of murder in Steven Biko (South Africa) in 1977 resolved through reconciliation. Ntsiki Biko, the wife of Steven Biko agrees to reconciliation, though he was still trying to seek justice. ${ }^{3}$

Reconciliation could be an alternative, although until recently did not appear to be the option chosen by the Government of Indonesia. ${ }^{4}$ The quest for justice against the mass killings in 1965 were full of twists and turns and minimal international support, is inversely related to cases of human rights violations in Timor-Timor were impressed easily and get great attention from the international community. The disparity in treatment of serious violations raises two big questions for us. The International Criminal Court (ICC) as international criminal justice body is formed by the United Nations - during cling to the Rome Statute to prosecute serious human rights violations around the world. At the opening of Rome Statute states: Conscious that all peoples are united by common bonds, their cultures pieced together in a shared heritage,

\footnotetext{
Satya Arinanto. (2008). Hak Asasi Manusia Dalam Transisi Politik Indonesia. Jakarta: Pusat Studi Hukum Tata Negara UI, p. 128

4 Ahmad Hambali. (2015). "Penyelesaian Pelanggaran Berat HAM Masa Lalu sebagai Pelaksanaan Pasal 28I ayat (2) UUD NRI Tahun 1945." Hasanuddin Law Review, 1(2): 266-281.
} 
and concerned that this delicate mosaic may be shattered at any time. ${ }^{5}$

From the dictum in Rome Statute is obvious that ICC as International Court to act on behalf of justice and equality. Each country is treated equally, and every person wherever has equal position to get basic rights as human. Therefore, as big question for us to the attitude of the United Nations which is so reactive in the enforcement of human rights in Timor-Timor, but so slow in human rights in the case of 1965 . This paper is going to look at the legal aspects and others underlying the differences in treatment based on the handling of human rights violations in 1965 and Timor-Timor.

\section{METHOD}

This study is a descriptive-qualitative. Qualitative study is highly relevant used to examine this issue, because the "style" of qualitative tried to construct reality and understand its meaning. Hence, qualitative research is usually very attentive processes, events and authenticity. ${ }^{6}$ Meanwhile, to prove the truth, this study will use a comparative study. Comparative research is a study that compared the presence of one or more variables at two or more different samples or at different times. ${ }^{7}$

\section{ANALYSIS AND DISCUSSION}

The implementation of International Peoples' Tribunal 1965 in Den Haag on 1013 November 2015 arise controversy in

5 Source: http://legal.un.org/icc/statute/english/rome statute(e).pdf Downloaded on 17 October 2016

6 Gumilar Rusliwa Soemantri. (2005). "Memahami Metode Kualitatif", Makara Sosial Humaniora, 9(2): 57-65

7 Sugiyono. (2006). Metode Penelitian Kuantitatif, Kualitatif, dan $R \& D$. Bandung: Alfabeta, p. 34
Indonesia. It was not separated from the issue of communism has long hided and suddenly rise back to the surface. But the dark history that is approximated to take 500.0001.000 .000 victims of Communist members and sympathizer indeed a burden of history that will continue to haunt Indonesia up to several tens of years. ${ }^{8}$

The fact that there was mass killing in 1965 is something that is undeniable. ${ }^{9}$ Mass killing were mostly experienced by Communist members or organizations affiliated with forcing a group of wives to become widows, an orphaned, and label "traitors" to their families without any known fault. There is not an impartial judicial process; there is a street court by the armed civilian forces. Military conduct omission, the police did not heed. In the end, killed millions of people die without any clarity. Even after the mass killing, the family of former communist is also experience discrimination in terms of access to education, health to the right to engage in politics. ${ }^{10}$

In the visible, it appears that a case 1965 have fulfilled the elements of serious human rights violations, as contained in the Rome Statute, namely the mass killings (genocide) and crimes against humanity. But why is the United Nations which historically known to be quite loud in voicing human rights enforcement is silent in the case of 1965. In fact, the UN has a wonderful history in its ef-

Chloe Pelegrini. (2012). Indonesia's Unresolved Mass Murders: Undermining Democracy, Tapol, 26 September 2012, p.3

9 Official document that published by CIA stating that fact it is true there has been a mass killing. But only, the exact number of how many victims still in question. According to the anti-PKI amounted to 87.000, US's embassy in Jakarta 250.000, while the Indonesian Government about 500.000

10 Chloe Pelegrini, Op.Cit, p. 3 
forts to uphold human rights values. The attitude of the United Nations in dealing with mass killings in Rwanda, the contribution of the UN to promote the fulfillment of the civil rights of former Yugoslavia is a good small piece of the United Nations in the fulfillment of human rights values. Even in Indonesia, the reactive of UN towards cases of conflict of Timor-Timor become a positive note, how the consistency of the UN as superintendent of human rights in the world.

The involvement of $\mathrm{UN}$ in the case of Timor-Timor is a release cause of 27 th province of Indonesia from the Unitary State of Republic of Indonesia. At the time, the Portuguese government which colonized Timor-Timor objected to the existence of human rights violations committed by the Government of Indonesia. On May 5, 1999 , the UNs' Security Council held a triangular agreement between the Government of Portugal, the Government of Indonesia, and the United Nations held in New York that the decision ordering the Government of Indonesia to maintain peace in Timor-Timor. Post-poll situation which resulted in the independence of Timor-Timor raising various violence such as murder, kidnapping, rape, destruction, theft of property, and, burning and destruction of military installations, offices and houses, and forcible evacuation. The uncertain situation to make the UNs' Security Council issued Resolution 1264 on September 15, 1999.

The contents of the resolution in addition to condemning the acts of violence in Timor-Timor, it also urged the government of Indonesia to try those most responsible for the violence through the Ad-Hoc Human

\section{Rights Court. ${ }^{11}$}

Both of events mentioned above, the events of 1965 or Timor-Timor seen serious human rights violations, namely genocide and crimes against humanity. But, although clearly visible, different treatment from the United Nations to the two cases in question together. To see to what extent the human rights violations that occurred in two cases, the authors wanted to see by conduct a comparison based on the definition of serious human rights violations made by the UN refers to the Rome Statute. But before that, the author will give a brief overview of the two incidents.

\section{Case Review of Human Rights Violations in $\mathbf{1 9 6 5}$}

The event of 1965 is one of mysteries that are difficult to unfold. In the span of time, a number of important witnesses who are involved directly or indirectly one by one began to fall, on the other hand the desire to uncover the case publicly and transparently impressed still half-hearted. It can be seen from year to year post-reform, where almost no president who really have a desire to investigate this case in more detail.

The event of 1965 begins with coup attempt by a group of military members with abducting 6 General who occupy important positions in Indonesia. The group is calling the movement as the 30 September Movement (Gestapu). In the afternoon, the group successfully mastered the RRI radio network and broadcast to the entire people that Gestapu have secured the President Soekarno

${ }_{11}$ Eddy O.S. Hiariej. (2010).Pengadilan atas Beberapa Kejahatan Serius Terhadap HAM, Jakarta: Erlangga, p. 84 
of a coup attempt by a group of military members. A few hours later, General Suharto managed to control TNI and thwart the course of the coup. And a few years later, President Soeharto managed to get rid of the President Soekarno from his position as president and then become President of Indonesia for 32 years. ${ }^{12}$

A few days after the failed coup carried out by Gestapu, the Generals who are victims of abduction and torture was found in the well bottom of Lubang Buaya. General Suharto then blame to the Indonesian Communist Party as the mastermind over the failed coup attempt. On 10 October 1965, on the basis of an attempt to do the restoration nationally and against the development of communism, Suharto establish Komando Operasi Pemulihan Keamanan dan Ketertiban (Komkamtib), an institution outside the constitution has power to control and unrestricted prevention. Through this institution, Soeharto indirectly considered ordered the mass killing of members of Indonesian Communist Party and its affiliates and sympathizers of former President Sukarno throughout the archipelago. ${ }^{13}$

Commandeered by the military, mass killings could have occurred from October 1965 to March 1966. The mass killing occurred largely in the province of Central Java, East Java, Bali and North Sumatra. This event is approximate to take between 500.000-1.000.000 victims. $^{14}$ After mass

Chloe Pelegrini, Op.Cit., Pages.4-5

13 Ibid

14 There is no definitive data that reveal how the victims in 1965. Because many victims are buried together, dumped in the river to have been abandoned. This figure is derived based on the monitoring of human rights activists who examined the events of 1965. See: Cf. Briere E., "Shadow play: Political mass murder and the killing that occurred in several months, President Soeharto also imprisons 750.000 people who are perceived as members of PKI. From a number of political prisoners, 800 people $(0.1 \%)$ were executed, while the rest remained in prison for years without obtaining justice it deserves. Although in 1970 the majority of them have been released, but approximate 55.000-100.000 people still in prison until $1977 .{ }^{15}$

Research result of Kontras stated that political prisoners are not really gain freedom. Their ID cards stamped with the writing of "ET" or ex-political prisoners. They have to report regularly to the military or the police, they do not have the freedom to move, the right of assembly and they revoked by the state, other than that they do not have access to jobs and education. ${ }^{16}$ Even in 1980-1990, the Government issued a regulation to conduct screening of all people who have blood ties, either directly or through marriage with ex-political prisoners; the government also cut off access them from work and fulfillment of civil rights such as health, education and a decent life. ${ }^{17}$

\section{Cases of Human Rights Violations in Timor-Timor}

Cases of human rights violations in TimorTimor began on 27 January 1999, when

1965 Indonesian coup" in Heribert Adam (ed.). (2011). Hushed Voices: Unacknowledged Atrocities of the 20th Century. Berkshire: Berkshire Academic Press, p. 167; McGregor K. "The Indonesian killings of 1965-66", Online Encyclopedia of Mass Violence, 4 August 2009, https://goo.gl/fiwLGZ Accessed on May 21, 2016

15 Chloe Pelegrini, Op.Cit, Pages 4-5.

16 VOA Indonesia. Available online at: www.voaindonesia.com/a/kontras-temukan-pelanggaran-ham-pascag30s/1349192.htmlAccessed on 17 October 2016

17 Kompas. Available online at: http://regional.kompas. com/read/2015/10/01/20414171/Kehidupan.Eks.Tapol. di.Kendari.Bebas.namun.Terpenjara.?page $=$ all Accessed on 17 October 2016 
the Indonesian government issued option involves the determination of the future of Timor-Timor is to reject or accept special autonomy through a poll. The poll results showed that most of the people of TimorTimor chose separation, with the details of 438.968 voters: 94.388 (21.5\%) chose the special autonomy and $344.580(78.5 \%)$ chose release. ${ }^{18}$

After the announcement of the poll results, there have been numerous violence causes casualties and damage will occur on a large scale to peoples' homes as well as other possessions. Beside that also allegedly occurred robbery, murder and rape massive in various area. After the Indonesian government issues two options on 5 May 1990 as a follow-up meeting of two countries in New York that is the Government of Indonesia and Portugal mediated by the United Nations, in Article 3 the agreement states: ${ }^{19}$

"The Indonesian government will be responsible for maintaining peace and security in Timor-Timor so that the consultation can be conducted in a fair and peaceful way in an atmosphere free of intimidation, violence and interference from any party."

In response to the violence in TimorTimor, on 15 September 1999, the UNs' Security Council issued a resolution No.1264 which condemns the violence that occurred after the popular consultation in TimorTimor. This resolution is also contains urging the Indonesian government to prosecute those responsible for violence.

The resolution gives the international mandatory to the Indonesian government to

\footnotetext{
18 Andrey Sujatmoko. (2005). Tanggung Jawab Negara Atas Pelanggaran Berat HAM Indonesia, Timor Leste dan Lainnya, Jakarta: Grasindo, p. 97

19 Ibid.
}

bring to justice those responsible for the violence that occurred in Timor-Timor through the Ad Hoc Human Rights Court. According to the UNs' Charter (Article 25) Indonesia is legally bound by the resolution. If do not obey, Indonesia could be in danger of losing its rights as a member of the United Nations up to release of membership.

The UNs' Human Rights Commission in Geneva, on 23-27 September 1999 held a special session on the situation in TimorTimor. The special session resulted in Resolution No.1999/S-4/1 that demand to the Indonesian government, among others, in cooperation with the Indonesian National $\mathrm{Hu}-$ man Rights Commission (Komnas HAM) to ensure those responsible for acts of violence and systematic violations of human rights will be tried. The resolution also asked the UNs' Secretary General to establish an international commission of inquiry into the composition of which is composed of experts in Asia and in cooperation with the Indonesian National Human Rights Commission. ${ }^{20}$

Following up on the UNs' resolution, President B.J Habibie then through the Human Right Commission established the Inquiry Commission on Human Rights Violations in Timor-Timor (KPP-HAM) on 22 September 1999 with the Decree 770/TUA/ IX/1999 then completed by Decree 797/ TUA/IX/ 1999 dated 22 October 1999. In line with the establishment of KPP-HAM, on 8 October 1999, President B.J Habibie also applies Decree No. 1 of 1999 on Human Rights Court. In the preamble section of the decree that the authorities prosecute serious human rights violations in accordance with

20 Ibid. 
the provisions of Article 104 paragraph (1) of Act 39 of 1999 on Human Rights are Human Rights Court.

In a report prepared in Jakarta on 31 January 2000, KPP-HAM claimed to have discovered the serious human rights violations, which include murder, slavery extermination, expulsions and forced evacuation as well as others action that inhuman against the civilian population, this is a violation of rights life, right to physical integrity, right to liberty, right to freedom of movement and settled as well as property rights.

\section{Aspects of Serious Human Rights Viola- tions in 1965 and Timor-Timor}

To look whether an event there is a violation of human rights or not, then its reference is the number of conventions agreed upon by the international forum as an act of serious human rights violations. Ifdhal Kasim, ${ }^{21}$ in his narrative states that there are 3 (three) conventions which clearly indicate an obligation to make the punishment of crimes against humanity, namely:

(1) Geneva Convention of 1949. At the Geneva Convention, there is a specific redefinition related "serious violation" of a war crime under international law which have individual liability and shall be prosecuted by the state. Serious violations included murder, torture or inhuman treatment, including biological experiments, causing great suffering or serious injury to body or health, destruction of property in excess militarily cannot be justified, intentionally did not give a chance to a

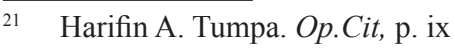

fair trial for the civilian population, and unlawful detention of civilians;

(2) Genocide Convention. It effective on 12 January 1952, and has been ratified by many countries. It provides absolute obligation to prosecute those responsible for genocide. The convention defines genocide as any of these actions, if done "with intent to destroy, in whole or in part, a national group, ethnic, racial or religious; and

(3) Torture Convention.

The three conventions above become references of international agreements on aspects of serious violations. But the human rights court jurisdiction prior to 1998 carried out separately in each city where human rights violations occur. Hence, in 1998, established the International Criminal Court (ICC), based in Rome. ICC to make the Rome Statute as the main reference in prosecuting serious violations. In addition to making a reference to the Rome Statute, the ICC also use the results of the serious human rights court previously performed in several cities in certain countries as a reference, namely:

(a) International Military Tribunal (IMT) Nurenberg;

(b) International Military Tribunal for the Far East (IMTFE) Tokyo;

(c) International Criminal Tribunal for the Former Yugoslavia (ICTY);

(d) International Criminal Tribunal for Rwanda (ICTR);

(e) Mixed International Court:

- Special Court for Sierra Leone;

- Extraordinary Chambers in the Court of Cambodia;

- Special Panels in Dili District Court. 
Human Rights and International Criminal Law

To look the extent to which the achievement of elements of serious human rights violations in the case of mass killing (genocide) in 1965 and Timor-Timor, it will not be able to escape relation to the Rome Statute. Based on Rome Statute, which include International human right serious violations is genocide, crimes against humanity, war and aggression crimes. In the events of 1965 and Timor-Timor, the approximated violation is genocide and crimes against humanity.

\section{Genocide}

In Rome Statute stated that the definition of genocide is an act, if committed with intent to destroy, or in part, a group, and national, ethnical, racial or religious. In Article 6 of Rome Statute mentioned acts including genocide is: ${ }^{22}$

a) Killing group members.

b) Causing injuries to the body or mental group members.

c) Deliberately inflicting on the group conditions of life that cause physical damage in whole or in part.

d) Wearing measures intended to prevent births within the group.

e) Forcibly transferring children of a group to another group

Seeing both cases discussed in the previous paragraph. In the events of 1965 mass killing is committed against certain groups, namely the group of former Communist and its affiliates, while in the event of TimorTimor the biggest victim is stating choose

22 Source: http://legal.un.org/icc/statute/english/rome statute(e).pdf accessed on 17 October 2016 pro-independence. Based on the above data, we can compare based on data collected from various sources.

Based on the data in Table 1, the actual a case of 1965 submitted to the ICC is compared to the events in Timor-Timor both by seeing the number of victim or damage that occurs after the event. However, in reality the event of 1965 until now has never been formally convened by the United Nations as a serious human rights violation. ${ }^{23}$

\section{Crimes against humanity}

Article 7 of the Rome Statute states that the definition of crimes against humanity:

"For the purpose of this Statute, "crime against humanity" means any of the following acts when committed as part of a widespread or systematic attack directed against any civilian population, with knowledge of the attack".

This article categorizes a crime against humanity to be more specific, namely: a) Murder; b) Slaughter; c) Slavery; d) Deportation or forced evacuation; e) Confinement or deprivation of physical liberty arbitrarily and in violation of fundamental rules of international law; f) Torture; g) Rape; h) Sexual slavery, forced prostitution, forced pregnancy, enforced sterilization or any other form of sexual violence; i) Oppression of a group known or against a political group, racial, national, ethnic, cultural, religious, gender or other groups that are universally not

23 Referring to the categorization of indigenous communities according to Clifford Gertz, indigenous communities could be divided into 3 (three), namely Islam, abangan and priyayi. At the time of conflict in 1965, Islamic groups through Anshor Group (NU) taken part in mass killing with them, there are greatest victims for abangan group 
Table 1. Comparison of Events in 1965 and Timor-Timor.

\begin{tabular}{lcc}
\hline \multicolumn{1}{c}{ Type } & Event $\mathbf{1 9 6 5}$ & Timor-Timor \\
\hline Victim dies & $500.000-1.000 .000$ & 1000 \\
Victim imprisoned & 750.000 & - \\
Group & Member of Communist (PKI) & Group Pro-Independence \\
Religion & Abangan & Christian \\
Perpetrator brought to justice & - & 18 \\
\hline
\end{tabular}

Source: Compiled from various sources.

Table 2. Comparison of Human Right Violation in 1965 and Timor-Timor

\begin{tabular}{lcc}
\hline \multicolumn{1}{c}{ Crimes } & $\mathbf{1 9 6 5}^{\mathbf{a}}$ & Timor-Timor $^{\mathbf{b}}$ \\
\hline Murder & Yes & Yes \\
Slaughter & Yes & Yes \\
Slavery & Yes & Unknown \\
Deportation or forced evacuation & Unknown & Yes \\
Confinement or deprivation of physical liberty arbitrarily & Yes & Unknown \\
Torture & Yes & Unknown \\
Rape & Ya & Unknown \\
Sexual slavery & Unknown & Unknown \\
Oppression of a group & Yes & Yes \\
Forced disappearances & Yes & Unknown \\
Apartheid & Unknown & Unknown \\
Other inhumane acts & Yes & Yes \\
\hline
\end{tabular}

${ }^{A}$ Related human rights violations based on the decision of the International People's Tribunal (IPT) 1965

${ }^{B}$ Related human rights violations based on the Ad Hoc Human Rights Court Decisions

Source: Compiled from various sources.

allowed in international law; j) Forced disappearances; k) Apartheid; 1) Other inhumane acts that causes severe suffering, serious injury to the body, mental or physical health of a person.

If we look at the events of 1965 or Timor-Timor, whether included in the category of crimes against humanity (Table 2). Based on data above, actually seen clearly that the level of human rights violations that occurred in the event of 1965 is heavier than Timor-Timor. This was due to the events of 1965 to get systemic omission from the international community, so that the number of violations that should be stopped persists continuously both quality and quantity offense victims.

\section{International Law Policy in Serious Hu- man Rights Violations}

Talking about the international law, we are talking about a large community of the world, with political interests and potential for conflict is high. But as a study of the science of law, international law certainly cannot be separated from the values of the substance of legal purposes. Gustav Radbruch in his thesis mentions that the purpose of the law there are three, namely justice (gerechtigkeit), legal certainty (rechtssicherheit) and utility (zweckmaßigkeit). ${ }^{24}$ In the absence of these three elements, legal not unlike noman figure, pilotless aircraft, or chicks lose

\footnotetext{
24 Heather Leawoods. (2000). "Gustav Radbruch: An Extraordinary Legal Philosopher", Washington University Journal of Law and Policy, Vol. 2, 489-515.
} 
their mother. But the extent to which the possibility of international law can step to meet these objectives cannot be separated from the political will from countries that have great strength and power.

Political conflict that triggers the World War II is history evidence where international law that upheld LBB (League of Nations) in the end as empty projectile, wherein when a number of countries did not heed the warnings issued, LBB could not take action. The content of International Law which is more of an agreement also affirmed in Article 38 paragraph (1) Statute of the International Court:

(1) The Court, Whose Function is to decide in accordance with international law such disputes as are submitted to it, shall apply.

a. International Covention, whether general or particular establishing rules expressly recognized by the constesting states.

b. International Customs, as evidence of a general practice accepted as law.

c. The general principles of law recognized by civilized nations.

d. Subject to the provisions of article 59, judicial decisions ad the teachings of the most highly qualified publicits of the various nations, as a subsidiary means for the determination of rules of law

(2) The provisions shall not prejudice the power of the court to decide a case ex aequo et bono if the parties agree.

It appears that agreement aspect is a main foundation. But in setting the collective agreement becomes very difficult, because the political element (the interests of each country is a major consideration). ${ }^{25}$

25 Masyhur Effendi. (1994). Hak Asasi Manusia Dalam Hukum Internasional. Jakarta: Ghalia Indonesia, p. 108
To read disparities in the resolve of serious human rights violations in 1965 and Timor-Timor in addition to using a legal perspective, we have to use the perspective of international politics. In the events of 1965 , since it the international community was hit by a prolonged cold war. The condition is forcing the international community is divided into two major groups, namely: Country Pro Uni Soviet and Pro USA.

War happens when it is not a physical war, but a war of technology and ideology. Technology war is done through a competition to create a rocket that can penetrate the outer space. Meanwhile, an ideological war carried out by importing an ideology to a new country gained its independence after World War 2. In the visible, the world was divided into 2 (two) ideological groups, namely:

1. Eastern Bloc (ideology of Communism): Poland, Yugoslavia, Finland, East Romania (Moldova), East Germany, Bulgaria, Hungary, Czechoslovakia, Romania, and Albania; and

2. Western Block (Ideology of Liberalism): West Germany, the UK, Norway, Netherlands, Portugal, France, etc.

On the other hand, there are a number of countries that declared itself as a group of Non-Aligned Movement (NAM) such as Indonesia and Egypt. But countries that are included in this group actually have a tendency to embrace a particular ideology.

Since that Indonesia is one of the potential country for grabs in the Southeast Asia region. The proximity of the President Soekarno to the ideology of communism by establishing shaft of Jakarta-Beijing in 1964 gave rise to concerns over liberalism 
dominance in Southeast Asia. As known, then several countries in the Southeast Asia region has embraced communism, such as Vietnam and Cambodia. Fear of a domino theory in which when there are countries that embrace the ideology of communism, then the surrounding countries would adopts a similar raises concerns the United States as leader of the Western Block.

In a report published by CIA (Central of Intelligence Agency) in December 1968 - an US's intelligence agencies - mention chronological events of 1965 in detail and depth. According to the report of what happened in Indonesia is indeed an insurgency by Communist. According to the report, there are 3 (three) big things that happen as a result of the events of 1965, namely: ${ }^{26}$

(1) A massive purge of the Communist party - organization in which thousands of people lost their lives in one of the ghastliest and most concentrated bloodlettings of current times;

(2) The toppling of President Sukarno, who before the coup had the stature of a demigod on the Indonesian scene; and

(3) 'A complete turnabout in the country's international alignment- from that of being one of Communist China's closest allies in growing estrangement from the rest of the world and one of the harshest critics of the West to a new posture of being a friend of the West, seeking the goodwill of all other nations of the world except Communist China

Support the United States and the UK is written also by Chloe Pelegrini, in his writing Indonesia's Mass Unresolved Murder. According to Chloe, on 5 October 1965 Po-

26 Source: www.cia.gov/library/readingroom/docs/esay40.pdf accessed on 17 October 2016 litical Adviser to the UK in Singapore writes a letter to the Ministry of Foreign Affairs, "Everything possible should be done surreptitiously to blacken the PKI in the eyes of the army and the people of Indonesia." On the same day they also sent letter to the British ambassador in Jakarta, which states that:

"A little shooting in Indonesia would be an essential preliminary to effective change in Indonesia" and that British participation "should be carefully concealed" 27

While the United States allegedly also contributed to supply the military with a list of PKI lead and supplying small arms labeled "medicines" to equip citizen soldiers, with the expectation as if the massacre was nothing more than a reaction civilian for the failure of the coup 1 October 1965.

Otherwise, the events in Timor-Timor, the role of US government are small. All legal proceedings rests entirely on the International Court of Justice, it was due to lack of international political interests that occur in these events. That is why a very large role in the international political influence to overcome the problem of serious human rights enforcement at the international level.

\section{CONCLUSION}

UNs' attitude that treat serious human rights violations in Timor-Timor and the events of 1965 cannot be answered differently in the perspective of international law, since it has a weakness where the political interests of ruling the country is very strong in influencing the UN's decision. Cases in 1965 are a case of serious human rights violations when

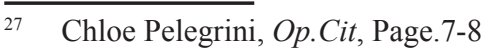


referring the Geneva Conventions, the Genocide Convention or the Rome Statute. This also applies to events in Timor-Timor. But when the events of 1965 occur, the cold war was raging violently. Meanwhile, when the UN was dominated by the Western Bloc that feel disadvantaged by such events, so that these cases go unpunished and are not considered as one of the serious human rights violations. On the other hand, the case of the release of Timor-Timor from Indonesia did not involve debate in international politics, so that the process is handed over to the applied legal mechanisms. Therefore, the presence of disparities in law enforcement in the event of serious human rights violations in 1965 and Timor-Timor due to the dynamics of international politics when it does not allow for the demands of human rights violations to the UNs' International Court because the advantages for certain countries after the incident occurred.

Referring to the genocide conventions or the Rome Statute, the events of 1965 clearly constitute serious violations and viable in international law filed at the International Criminal in Rome. We have to recognise that international politics has big impact in influencing the UNs' decision to classify these events as part of the serious human rights violations. Therefore, in order to reduce disparities in human rights violations, reconciliation is the most rational solution at this time compared remains demand the state for the violations. Besides, many human rights violations in certain countries that have successfully resolved through reconciliation.

\section{BIBLIOGRAPHY}

Ahmad Hambali. (2015). "Penyelesaian Pelanggaran Berat HAM Masa Lalu sebagai Pelaksanaan Pasal 28I ayat (2) UUD NRI Tahun 1945." Hasanuddin Law Review, 1(2): 266-281.

Andrey Sujatmoko. (2005). Tanggung Jawab Negara Atas Pelanggaran Berat HAM Indonesia, Timor Leste dan Lainnya, Jakarta: Grasindo.

Chloe Pelegrini. (2012). Indonesia's Unresolved Mass Murders: Undermining Democracy, Tapol, 26 September 2012.

Eddy O.S. Hiariej. (2010).Pengadilan atas Beberapa Kejahatan Serius Terhadap HAM, Jakarta: Erlangga.

Geoffrey Robinson, "People's war: Militias in East Timor and Indonesia", Journal South East Asia Research, 9(3): 271318.

Gumilar Rusliwa Soemantri. (2005). "Memahami Metode Kualitatif”, Makara Sosial Humaniora, 9(2): 57-65.

Harifin A. Tumpa. (2010). Peluang dan Tantangan Eksistensi Pengadilan HAM di Indonesia. Jakarta: Kencana.

Heather Leawoods. (2000). "Gustav Radbruch: An Extraordinary Legal Philosopher", Washington University Journal of Law and Policy, Vol. 2, 489-515. Heribert Adam (ed.). (2011). Hushed Voices: Unacknowledged Atrocities of the 20th Century. Berkshire: Berkshire Academic Press.

Kompas. Available online at: https://goo. gl/L8GQBR Accessed on 17 October 2016. 
Masyhur Effendi. (1994). Hak Asasi Manusia Dalam Hukum Internasional. Jakarta: Ghalia Indonesia.

McGregor, K. "The Indonesian killings of 1965-66", Online Encyclopedia of Mass Violence, 4 August 2009. Available from: https://goo.gl/2dl7Ju Accessed on 16 May, 2016.

Satya Arinanto. (2008). Hak Asasi Manusia Dalam Transisi Politik Indonesia. Ja- karta: Pusat Studi Hukum Tata Negara UI.

Sugiyono. (2006). Metode Penelitian Kuantitatif, Kualitatif, dan R\&D. Bandung: Alfabeta.

VOA Indonesia. Available online at: www.voaindonesia.com/a/kontrastemukan-pelanggaran-ham-pascag30s/1349192.html Accessed on 17 October 2016. 